\title{
Australia also seeks industrial innovation for prosperity
}

\section{Perth, Western Australia}

A NEW broom began to sweep the floor of Australian science at Australia's largest regular academic gathering here from 16 to 20 May - but only gently.

About 3,500 delegates attended the 33rd congress of the Australian and New Zealand Association for the Advancement of Science (ANZAAS), held in the spacious green environs of the University of Western Australia, the Western Australian Institute of Technology and Murdoch University. The balmy autumn weather may have tranquillized them into placid acceptance of the offerings of nearly a thousand papers and symposia, but there were only a few debates and, as usual, ANZAAS ended without a sense of progress in any direction.

Indeed, the sensation of this year's ANZAAS had nothing to do with science but with crime. Mr Douglas Meagher, senior counsel assisting the Royal Commission on the activities of the Federated Ship Painters and Dockers Union, issued at the very start of the congress a 213-page collection of revelations of the extent of organized crime throughout Australia, which at least allowed newspapers to add pointers to "other ANZAAS stories" otherwise buried on inside pages.

Between the planning of this congress over a year ago and last week, the economic and political climate of Australia had changed dramatically. The congress theme of "resources and responsibility" was more relevant to the erstwhile boom in exports of Australia's natural resources than to the current period of recession.

The new Labor Government has inherited from its Conservative predecessor an inflation rate of more than 11 per cent and an officially acknowledged unemployment rate of 9 per cent. The realization that economic recovery will be slow and painful is spreading, tempering expectations that the Labor election victory would lead to an early expansion of federal support for science.

Political priorities were highlighted by the failure of Mr Barry Jones, the new Minister for Science and Technology, to attend the ANZAAS meeting, a gathering normally embraced by the holder of his portfolio. Mr Jones was caught up in the crucial first parliamentary session of the new government, which brought down a cost-cutting mini-budget while the ANZAAS meeting was in progress. $\mathrm{Mr}$ Jones did take part, however, in one symposium by remote electronic means.

ANZAAS becomes more and more a non-scientific beast wearing the clothes of science. The social sciences and humanities (including not only law and economics but musicology and women's studies) provided the great majority of the papers in the 34 specialized sections. In science proper, because presentation of a paper at an ANZAAS congress seldom leads to formal publication, participation and originality are inhibited, while the fact that ANZAAS papers are not refereed reduces their professional value.

Nonetheless, ANZAAS is not dying. Indeed, the organizers were exceptionally successful in attracting funds to bring 50 speakers of substance from overseas (more than at any previous congress) and in persuading hundreds of delegates to travel from the eastern states.

The new broom this year was that of encouraging technological innovation and development. The sweepers were led by Professor Ralph Slatyer, president of the congress, who is the new chairman of the Australian Science and Technology Council (having been appointed before the Malcolm Fraser government was defeated). A biologist at the Australian National University and a former Australian ambassador to UNESCO, he has a pivotal role in advising the Prime Minister on priorities for science and technology, including the programmes submitted by Mr Jones's own department.

In what would have been music to $\mathrm{Mr}$ Jones's distant ear, Professor Slatyer urged immediate action to improve Australia's economic performance and industrial competitiveness through accelerated technological innovation. He pitched his appeal for a major investment in research and education in terms of its potential effect on economic recovery and creation of jobs - a note tuned also to the ear of Prime Minister Bob Hawke, whose depth of interest in science and technology has yet to be publicly revealed.

Professor Slatyer illustrated his concern about Australia's capacity to lift itself out of recession by pointing out that less than 40 per cent of young Australians are enrolled full-time in the final years of secondary school, compared with more than 80 per cent in the United States and Japan. Further, since 1976, the numbers of students proceeding to full-time higher education have declined by 18 per cent, while on a per capita basis Australia has only about one-third as many engineers as Japan (24 as against 70 per 10,000 of population).

Slatyer also asserted that Australian science "appears to be as good as anywhere in the world" but that while Australian scientists produce some 2 per cent of the world's scientific knowledge, they are responsible for only 0.7 per cent of world patents on which technological innovation is based. The isolation of scientific institutions from industry, little in-house research and development in industry (much of it foreign-owned) and cuts in funds for universities and for overseas contacts by scientists were cited by Professor Slatyer as priorities for correction.

One of the few speakers also to reflect the potential economic influences of a shift towards new technology was Dr Ken McCracken, chief of the Commonwealth Scientific and Industrial Research Organization's Division of Mineral Physics. He came down solidly in favour of a "Buy Australian" policy as the key element in an array of support mechanisms

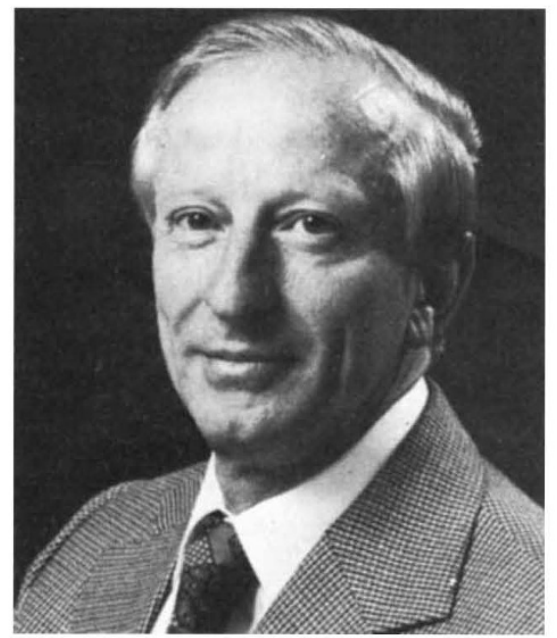

Ralph Slatyer . . . urging more technological innovation

for selected industries, such as communications, small computers, nucleonics, word processing and electronic mail. Dr McCracken estimated a total expenditure within Australia after three years of about A $\$ 300$ million per annum and about 3,000 man-years of employment, before taking multiplier effects into account.

On Australian physics, formerly an area of notable innovation as in radio science, McCracken urged his fellows to speak up about the way government should help to turn the results of research into profit - or else they would find that funds for their research would dry up.

Although the communication of science to the public, one of the aims of every ANZAAS congress, was notable this year principally for its failure, the topic was examined in a special symposium. A survey of 31 editors of major newspapers, television and radio news services throughout Australia has revealed a generally unflattering image of scientists among these agenda-setters. The number of full-time science reporters in the Australian commercial media can be counted on one hand. There appeared to be agreement among those at this symposium that unless a better informed, more public profile for science and technology can be generated, the road to government-inspired initiatives in the future will be rocky indeed. Peter Pockley 